\title{
EFFECTS OF SPATIAL VARIABILITY OF SOIL CHEMICAL PARAMETERS ON TIFTON 85 GRASS YIELD ${ }^{1}$
}

\author{
EUDOCIO RAFAEL OTAVIO DA SILVA ${ }^{2}$, MURILO MACHADO DE BARROS ${ }^{2}$, MARCOS GERVASIO PEREIRA ${ }^{3 *}$, \\ JOÃO HENRIQUE GAIA GOMES ${ }^{3}$, STEPHANY DA COSTA SOARES ${ }^{4}$
}

\begin{abstract}
Studies on spatial variability of soil attributes of tropical pastures gather information that can assist in decision making about managements of these soils. The objective of the present study was to evaluate the spatial variability of soil chemical attributes and their effects on grass yield of Tifton 85 . The experiment was carried out in an area of 3.91 ha at the Feno Rio Farm of the Federal Rural University of Rio de Janeiro, Seropédica, RJ, Brazil. Soils of the 0-0.20 and 0.20-0.40 m layers were sampled considering an irregular sampling mesh, making a total of 50 georeferenced points. The parameters evaluated were: the soil chemical attributes $\mathrm{pH}, \mathrm{Al}^{+3}, \mathrm{Ca}^{+2}, \mathrm{Mg}^{+2}, \mathrm{Na}^{+}, \mathrm{K}^{+}, \mathrm{P}, \mathrm{H}+\mathrm{Al}$, and total organic carbon (TOC); and the Tifton 85 dry matter yield (DMY). The results of these parameters were subjected to descriptive statistics, linear correlation, and geostatistics, and maps were developed for the analyses. Regions with grass yields different from the general mean were found in the area, which presented mean grass yield of $2248 \mathrm{~kg} \mathrm{ha}^{-1}$. The soil chemical parameters $\mathrm{Na}^{+}, \mathrm{Ca}^{+2}$, TOC, and $\mathrm{H}+\mathrm{Al}$ were significantly correlated with DMY, confirming that they are important and affect the Tifton 85 grass yield. The mapping of the Tifton 85 cycle is important for understanding the variability of DMY. The investigation of areas with different productive potentials should be followed by development of maps of soil chemical attributes to correlate and understand the ratios that may be involved with these variations.
\end{abstract}

Keywords: Precision agriculture. Spatial dependence. Geostatistics.

\section{VARIABILIDADE ESPACIAL DE PARÂMETROS QUÍMICOS DO SOLO E SEUS EFEITOS NA PRODUTIVIDADE DA TIFTON 85}

\begin{abstract}
RESUMO - Os estudos sobre a variabilidade espacial de atributos do solo de pastagens tropicais buscam conhecimentos que possam auxiliar nas tomadas de decisões sobre os manejos destes solos. O presente estudo teve como objetivo avaliar a variabilidade espacial de atributos químicos do solo e seus efeitos na produtividade de área cultivada com Tifton 85. O experimento foi realizado na Fazenda Feno Rio, localizada na Universidade Federal Rural do Rio de Janeiro, em Seropédica, em uma área de 3,91 ha. Os solos foram amostrados em malha irregular, perfazendo o total de 50 pontos georreferenciados, nas profundidades de $0-0,20$ e 0,20-0,40 m. Foram analisados os atributos químicos do solo $\mathrm{pH}$ em água, $\mathrm{Al}^{+3}, \mathrm{Ca}^{+2}, \mathrm{Mg}^{+2}, \mathrm{Na}^{+}, \mathrm{K}^{+}, \mathrm{P}, \mathrm{H}+\mathrm{Al}$ e COT, além da massa seca (MS) da Tifton 85 para avaliação da produtividade. A partir destes parâmetros foram realizadas análises de estatística descritiva, correlação linear, geoestatística e geração de mapas. Foi possível inferir diferentes zonas de produtividade em relação à média geral, verificando-se que a produtividade média na área foi de $2.248 \mathrm{~kg} \mathrm{ha}^{-1}$. Os parâmetros químicos do solo $\mathrm{Na}^{+}, \mathrm{Ca}^{+2}, \mathrm{COT}$ e $\mathrm{H}+\mathrm{Al}$ correlacionaram significativamente com a MS, confirmando serem importantes e interferirem na produtividade da Tifton 85 . Percebeu-se que a realização de mapeamentos ao longo do ciclo da Tifton 85 são importantes na compreensão da variabilidade da produção de MS e a investigação de áreas com diferentes potenciais produtivos deve ser acompanhada de mapas de atributos químicos do solo, buscando correlacionar e entender as razões que podem estar envolvidas nestas variações.
\end{abstract}

Palavras-chave: Agricultura de precisão. Dependência espacial. Geoestatística.

\footnotetext{
${ }^{*}$ Corresponding author

${ }^{1}$ Received for publication in 04/04/2019; accepted in 10/22/2019.

Paper extracted from the monograph of the first author.

${ }^{2}$ Institute of Technology, Department of Engineering, Universidade Federal Rural do Rio de Janeiro, Seropédica, RJ, Brazil; eudociootavio@hotmail.com - ORCID: 0000-0002-5609-3184, egmurilo@yahoo.com.br - ORCID: 0000-0003-0378-4800.

${ }^{3}$ Institute of Agronomy, Department of Soils, Universidade Federal Rural do Rio de Janeiro, Seropédica, RJ, Brazil; mgervasiopereira01@gmail.com - ORCID: 0000-0002-1402-3612, gaia.gomes.pgeaamb@gmail.com - ORCID: 0000-0003-3870-7258.

${ }^{4}$ Department of Agricultural and Environmental Engineering, Universidade Federal Fluminense, Niterói, RJ, Brazil; eng.stephanycosta@gmail.com - ORCID: 0000-0002-6622-6147.
} 


\section{INTRODUCTION}

Pastures in Brazil presents great production potential because of the tropical climate of the country. However, the low natural fertility of its soils, absence of reposition of nutrients extracted by forages, inadequate nutrition of pastures (GIOSTRI et al., 2014; PIAS et al., 2015), and lack of planning of actions for soil fertilization and correction of soil acidity have resulted in degradation of these areas.

Therefore, rural producers have search for technologies and managements that improve their cultural practices for production and soil conservation in tropical pastures, especially those who use areas for animal grazing and hay and silage production.

Soils present heterogeneity due to the variability in their chemical and physical attributes from their natural formation and managements (SOARES et al., 2018), thus, the application of fertilizers and soil conditioners at variables rates is an alternative with great potential.

Information on the contents of nutrients that limit plant development and improve the pasture production is important, since it allows an adequate planning for soil fertilization.

The use of geostatistics and strategies for georeferenced sampling is important to generate information on spatial variability of soil attributes (AQUINO et al., 2014), since they allow the detection of the existing variability and spatial distribution of the study parameter, and the understanding of factors and characteristics that affect, in some way, the crop productive development, thus assisting in decision making for soil managements.

Grass species of the genus Cydonon is among forages that became important due to their production capacity and higher resistance to seasonality, especially the Tifton 85 , when compared to species of other genera. Tifton 85 (Cynodon spp.) presents good adaptation to tropical and subtropical conditions; it was developed to produce forages of high grass yield and quality (GOMES et al., 2015). However, it is one of the forages that present high nutritional demand for their satisfactory development (COUTINHO et al., 2014).

Despite the many studies on the growth of Tifton 85 in different systems (COLUSSI; SILVA; MINATO, 2014; GOMES et al., 2015; SIMÕES et al., 2015; POCZYNEC et al., 2016; ALMEIDA et al., 2019), few of them evaluated the correlation between soil chemical and physical attributes and forages of the genus Cynodon involving precision agriculture tools.

In this context, the objective of the present work was to evaluate the effects of spatial variability of soil chemical attributes on the grass yield of an area with Tifton 85

\section{MATERIAL AND METHODS}

The experiment was conducted at the Feno Rio Farm of the Federal Rural University of Rio de Janeiro (UFRRJ), in Seropédica, state of Rio of Janeiro, Brazil. The geographic coordinates of the area were $22^{\circ} 47^{\prime} 27.68^{\prime \prime S}$ and $43^{\circ} 40^{\prime} 49.24^{\prime \prime} \mathrm{W}$. The study area had $39,067.71 \mathrm{~m}^{2}$ (3.91 ha), mean altitude of $26 \mathrm{~m}$, a plain relief in the whole area (little slope), and was used to grow Tifton 85 (Cynodon spp.) grass for hay production.

The climate of the region is Aw, according to the Köppen classification, with rainfall concentrated between November and March, average annual compensated temperature of $23.9{ }^{\circ} \mathrm{C}$, and average annual rainfall depth of $1213 \mathrm{~mm}$. The soil of the area was classified as Typic Hapludult-Argissolo Vermelho-Amarelo Distrófico típico, according to the soil survey of the UFRRJ conducted by Ramos, Castro and Camargo (1973).

The area was fallow before the Tifton 85 planting, which was done by broadcast seeding with subsequent uniform applications of lime, and nitrogen, phosphorus, and potassium fertilizers (conventional soil fertilization) in the whole area; this management was consecutively used every new cycle of the grass for hay production, with no grazing of animals.

First, the experimental area was investigated in a survey to better understand the spatial variability of the soil attributes to be studied, and to subsidize soil management actions for agriculture, such as input applications. The survey of the area showed regions with good plant development for Tifton 85 , with high productive potential; and spots with poor plant development for Tifton 85, with low productive potential. Therefore, the soil sampling required georeferencing to evaluate chemical attributes for the investigation of the grass yield of the area.

The sampling mesh proposed for the experimental area was based on 50 collection points, with a sampling density of 12.8 points per hectare in an irregular mesh and random sampling, according to Yamamoto and Landim (2013), to represent the whole area and explore the local variability (Figure 1). 


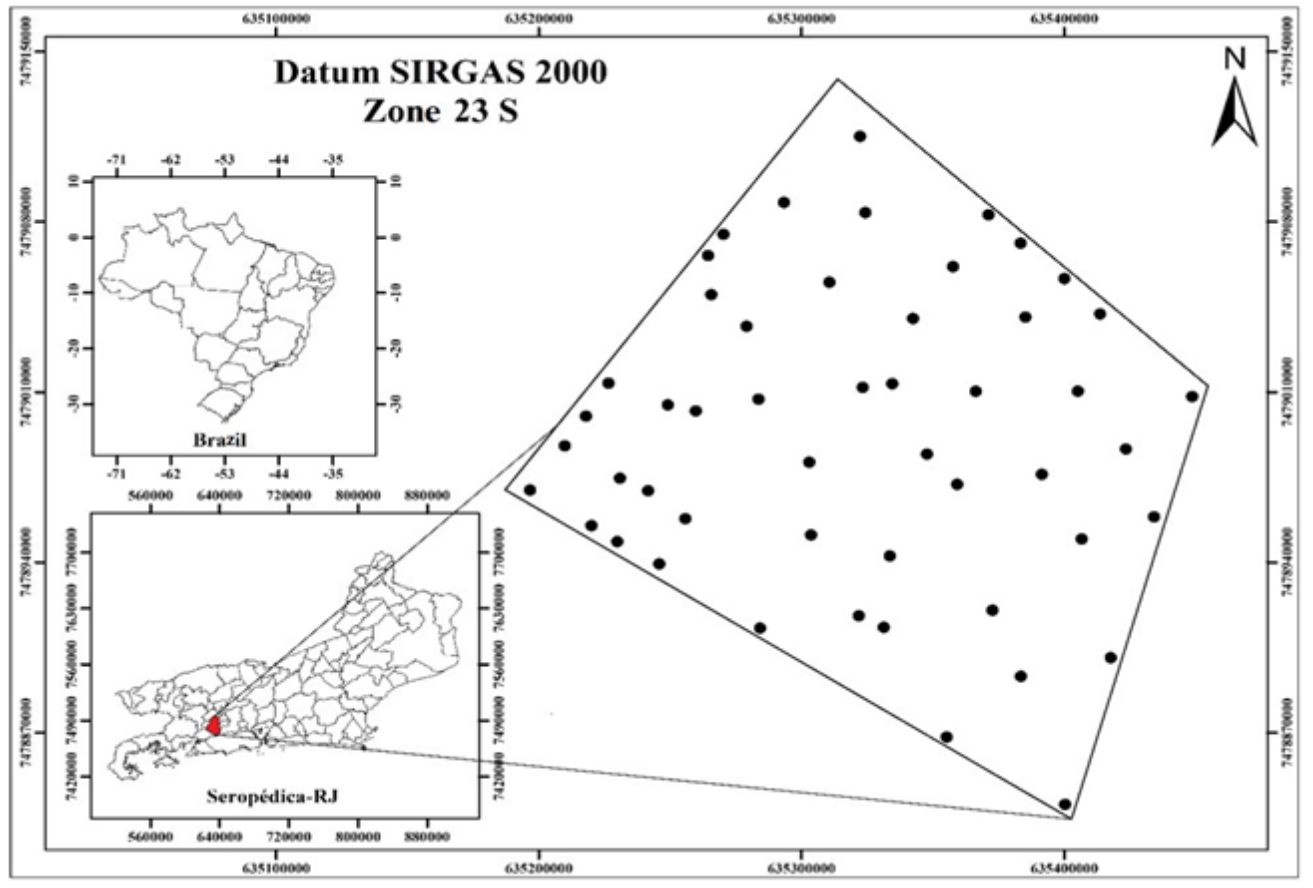

Figure 1. Sampling mesh proposed for the experimental area.

All sampling points were georeferenced and collected using a total station (TPS300 Basic Series; Leica Geosystems, Heerbrugg, Switzerland) based on the use of a Euclidian plane. The georeferencing process required adjustments to the survey, since all coordinates obtained were of local type and not latitude and longitude. Thus, mathematical calculations were made to know the geographical coordinates of the points surveyed with the device and, thus, obtaining their 2-dimensional Cartesian coordinates UTM (Universal Transversa of Mercator) for the $23 \mathrm{~S}$ zone, where the Seropédica region is located.

Disturbed soil samples from the $0-0.20 \mathrm{~m}$ and $0.20-0.40 \mathrm{~m}$ layers were collected in each sampling point, totaling 100 samples. Then, the samples were air dried, disaggregated, and sieved in a $2.00-\mathrm{mm}$ mesh sieve to obtain an air-dried fine earth (TEIXEIRA et al., 2017), which was the material used for the analyses. These analyses consisted of evaluations of $\mathrm{pH}$, using soil in water $(1: 2.5)$; exchangeable calcium (Ca), magnesium ( $\mathrm{Mg})$, potassium $(\mathrm{K})$, sodium $(\mathrm{Na})$, and aluminum ( $\mathrm{Al}$ ); available phosphorus $(\mathrm{P})$; and extractable hydrogen + aluminum $(\mathrm{H}+\mathrm{Al})$ (potential acidity), according to Teixeira et al. (2017); and estimations of total organic carbon (TOC), according to Yeomans and Bremner (1988).

The grass yield was evaluated by positioning a $0.35-\mathrm{m}^{2}$ rectangular frame around the sampling points, which delineated the sampled area, cutting the grass that was within this area, collecting the grasses to evaluate their dry matter yield (DMY). After the collection, the samples were weighed to determine their fresh weight, then dried in a forced- air circulation oven at $65^{\circ} \mathrm{C}$ until constant weight to determine their DMY.

The results of chemical attributes and grass yield were subjected to descriptive statistics and to geostatistical analysis. The agricolae bibliotheca of the R program was used for the descriptive statistics (DELGADO, 2018). The data were used to obtain the measures of position (minimum, mean, and maximum) and dispersion (coefficients of variation, asymmetry, and kurtosis).

The $\mathrm{CV}$ values were classified according to Pimentel-Gomes and Garcia (2002) as low (CV < $10 \%)$, medium $(10<\mathrm{CV}<20 \%)$, high $(20<\mathrm{CV}<$ $30 \%)$, and very high $(\mathrm{CV}>30 \%)$. The hypothesis of normality was tested by the $\mathrm{W}$ teste at $5 \%$ significance (SHAPIRO; WILK, 1965).

A correlation matrix was developed to obtain the Pearson's linear correlation index $(p<0.10)$, which resulted in simple linear correlations for pairto-pair combinations between the evaluated attributes to verify the correlation between the chemical parameters and the grass yield of Tifton 85 . The corrplot bibliotheca of the $\mathrm{R}$ program was used to develop the correlation matrix.

The $g e o R$ bibliotheca of the $\mathrm{R}$ program was used for the geostatistical analyses (RIBEIRO JUNIOR; DIGGLE, 2001). The semivariograms were calculated according to the method described by Vieira et al. (1983), described in Equation 1:

$$
\hat{\gamma}(h)=\frac{1}{2 N(h)} \sum_{i=1}^{N(h)}\left[Z\left(x_{i}\right)-Z\left(x_{i}+h\right)\right]^{2}(1)
$$

where $\hat{\gamma}(h)$ is the estimated semivariance; $N$ $(h)$ is the number of experimental pairs of observations; $Z\left(X_{i}\right)$ and $Z\left(X_{i}+h\right)$ are values of the 
evaluated attributes in the position $x i$ and $x i+h$, separated by a vector $h$ (distance between samples).

Semivariances $\hat{\gamma}(h)$ were calculated for each soil chemical attribute, obtaining the graph of semivariance of the data as a function of distance between the points (h), representing the semivariogram. Fitting the semivariograms to a mathematic model that described continuously the spatial correlation of each studied parameter was necessary. The models tested were the spherical, exponential, and gaussian.

The best fitted model was the one that presented the lower residual sum of squares (RSS) and the better coefficient of determination of the cross validation $\left(\mathrm{R}^{2} \mathrm{CV}\right)$ among the models tested (YAMAMOTO; LANDIM, 2013). After the fit of the mathematical model and calculation of semivariogram values, the coefficients of theoretical model were estimated for the model: nugget $(\mathrm{C} 0)$, sill $(\mathrm{C} 0+\mathrm{C} 1)$, and range, as described by Vieira et al. (1983).

The spatial dependence level of the attributes was verified using the classification of Cambardella et al. (1994), where $[(\mathrm{C} 0 /(\mathrm{C} 0+\mathrm{C} 1)]<25 \%$ represents a strong spatial dependence, [( $\mathrm{C} 0 /$ (C0 $+\mathrm{C} 1)]=25 \%$ to $75 \%$ represents a moderate spatial dependence, and $[(\mathrm{C} 0 /(\mathrm{C} 0+\mathrm{C} 1)]>75 \%$ represents a weak spatial dependence.

Subsequently, the data were exported to the ArcGis ${ }^{\circledR}$ 10.5.2 program (ESRI, 2016)-license for the Department of Environmental Sciences (DCA) of the Forest Institute of the UFRRJ - and subjected to interpolation by ordinary kriging to enable the visualization of spatial distribution patterns of the variables in the study area to develop the maps for each chemical parameter and grass yield in the metrical coordinates UTM $23 \mathrm{~S}$ zone.

The grass yield maps were divided into different classes, based on the following criteria: grass yield values higher than $100 \%$ of the mean grass yield of the area were classified as very high; $80 \%$ to $100 \%$ as high; $60 \%$ to $80 \%$ as medium; $40 \%$ to $60 \%$ as low, and values lower than $40 \%$ as very low.

\section{RESULTS AND DISCUSSION}

The results of the descriptive statistics of chemical attributes in the two soil layers $(0-0.20 \mathrm{~m}$ and $0.20-0.40 \mathrm{~m}$ ) are presented in Table 1.

Table 1. Descriptive statistics for chemical attributes of two layers of soils collected at points of a sampling mesh, and for grass yield of Tifton 85 .

\begin{tabular}{|c|c|c|c|c|c|c|c|c|c|}
\hline Variable & $\mathrm{P}$ & $\mathrm{K}$ & $\mathrm{Ca}$ & $\mathrm{Mg}$ & $\mathrm{Al}$ & $\mathrm{Na}$ & $\mathrm{H}+\mathrm{Al}$ & $\mathrm{pH}$ & TOC \\
\hline & $\mathrm{mg} \mathrm{kg}^{-1}$ & 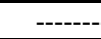 & $\cdots$ & --------- $\mathrm{cmol}$ & $\mathrm{n}^{-3}-\cdots-\cdots$ & - & ---------- & $\mathrm{H}_{2} \mathrm{O}$ & $\mathrm{g} \mathrm{kg}^{-1}$ \\
\hline \multicolumn{10}{|c|}{$0-0.20 \mathrm{~m}$ soil layer } \\
\hline Minimum & 0.00 & 0.01 & 1.2 & 1.20 & 0.50 & 0.16 & 1.16 & 4.52 & 10.44 \\
\hline Mean & 0.01 & 0.09 & 1.68 & 1.76 & 0.80 & 0.17 & 5.06 & 5.00 & 21.93 \\
\hline Median & 0.02 & 0.09 & 1.70 & 1.60 & 0.60 & 0.16 & 4.32 & 5.03 & 22.55 \\
\hline Maximum & 0.06 & 0.26 & 2.20 & 3.00 & 1.30 & 0.19 & 11.77 & 5.22 & 28.85 \\
\hline $\mathrm{CV}^{(2)}(\%)$ & 100 & 91.0 & 17.92 & 24.49 & 30.73 & 5.21 & 50.34 & 3.39 & 19.15 \\
\hline Asymmetry & 3.34 & 0.10 & 0.16 & 1.52 & 0.63 & 1.24 & 0.57 & -0.83 & -0.67 \\
\hline Kurtosis & 9.91 & -1.86 & -1.05 & 1.69 & -1.23 & 0.65 & -0.48 & 0.16 & -0.25 \\
\hline $\mathrm{W}$ test $^{(1)}$ & $0.372^{\mathrm{ns}}$ & $0.721^{\mathrm{ns}}$ & $0.945^{\mathrm{ns}}$ & $0.863^{\mathrm{ns}}$ & $0.816^{\mathrm{ns}}$ & $0.787^{\mathrm{ns}}$ & $0.947^{\mathrm{ns}}$ & $0.929^{\mathrm{ns}}$ & $0.940^{\mathrm{ns}}$ \\
\hline \multicolumn{10}{|c|}{$0.20-0.40 \mathrm{~m}$ soil layer } \\
\hline Minimum & 0.00 & 0.01 & 0.50 & 0.73 & 0.30 & 0.17 & 0.65 & 4.80 & 5.69 \\
\hline Mean & 0.01 & 0.01 & 1.26 & 1.32 & 1.47 & 0.18 & 4.32 & 5.04 & 17.07 \\
\hline Median & 0.02 & 0.01 & 1.10 & 1.20 & 1.40 & 0.18 & 3.46 & 4.99 & 18.82 \\
\hline Maximum & 0.08 & 0.02 & 2.50 & 2.90 & 3.70 & 0.21 & 9.12 & 5.44 & 25.13 \\
\hline CV $(\%)$ & 100 & 24.41 & 45.11 & 41.90 & 51.29 & 7.05 & 62.92 & 3.71 & 31.32 \\
\hline Asymmetry & 3.45 & 1.65 & 0.84 & 1.25 & 0.88 & 0.50 & 0.32 & 0.61 & -0.42 \\
\hline Kurtosis & 10.77 & 0.76 & -0.39 & 1.15 & 0.97 & 0.45 & -1.36 & -0.91 & -0.82 \\
\hline $\mathrm{W}$ test & $0.340^{\mathrm{ns}}$ & $0.467^{\mathrm{ns}}$ & $0.901^{\mathrm{ns}}$ & $0.959 *$ & $0.943^{\mathrm{ns}}$ & $0.897^{\mathrm{ns}}$ & $0.927^{\mathrm{ns}}$ & $0.912^{\mathrm{ns}}$ & $0.944^{\mathrm{ns}}$ \\
\hline \multicolumn{10}{|c|}{ Grass yield of Tifton $85\left(\mathrm{~kg} \mathrm{ha}^{-1}\right)$} \\
\hline Variable & Mean & Median & Maximum & Minimum & $\mathrm{SD}^{(3)}$ & $\mathrm{CV}$ & Asymmetry & Kurtosis & \\
\hline DMY & 2248 & 2009 & 5752.10 & 383.92 & 1206 & $54 \%$ & 0.67 & 0.31 & \\
\hline
\end{tabular}

${ }^{1} \mathrm{~W}$ test $=$ Teste of Shapiro-Wilk for normal distribution, where: ${ }^{\mathrm{ns}}=$ not significant. $*=$ significant at $\mathrm{p} \leq 0.05$, and nonsignificance indicates that the normal distribution hypothesis is rejected; ${ }^{2} \mathrm{CV}=$ coefficient of variation; ${ }^{3} \mathrm{SD}=\operatorname{standard}$ deviation.

The asymmetry results showed asymmetric distributions for the evaluated attributes. The attributes $\mathrm{pH}$ (0-0.20 m layer) and TOC (both layers) presented negative coefficient of asymmetry, indicating a trend of higher number of values higher than the mean. Positive asymmetry pattern was found for all other chemical parameters analyzed.

The Shapiro-Wilk test (W) showed that the attributes presented not normal distributions, except for $\mathrm{Mg}$ in the $0.20-0.40 \mathrm{~m}$ soil layer. However, according to Carvalho, Silveira and Vieira (2002), 
theoretical values of asymmetry and kurtosis of approximately 0 and 3 , respectively, indicate normality of the data. Thus, all chemical parameters evaluated presented a trend of normality of data, except for $\mathrm{P}$ in both layers, whose data were not normal by the Shapiro-Wilk test.

The normality of the dados is confirmed by the mean and median of the parameters evaluated, which were very similar to the values of the database, indicating that they are not atypically dependent on distribution and, thus, presented no pronounced asymmetry (CAMBARDELLA et al., 1994). The normality of the data allows a better prediction of the values of non-sampled points through geostatistics; although it is not required, it is a desirable characteristic (ISAAKS; SRIVASTAVA, 1989).

The coefficients of variation $(\mathrm{CV})$ were lower than $10 \%$ in both soil layers only for $\mathrm{pH}$ and $\mathrm{Na}^{+}$, whose variations were classified as low, according to Pimentel-Gomes and Garcia (2002), indicating homogeneity of these attributes in the study area. Medium CV $(10<\mathrm{CV}<20 \%)$ was found for $\mathrm{Ca}^{+2}$ and TOC, both in the $0-0.20 \mathrm{~m}$ layer; high CV $(20<$ $\mathrm{CV}<30 \%)$ was found for $\mathrm{Mg}^{+2}(0-0.20 \mathrm{~m})$ and $\mathrm{K}^{+}(0.20-0.40 \mathrm{~m})$; and very high $\mathrm{CV}(\mathrm{CV}>30 \%)$ was found for the other evaluated parameters.

A high $\mathrm{CV}$ is the first indicator of data heterogeneity of a variable, which can be related to effects of soil formation and management. The high $\mathrm{CV}$ for $\mathrm{P}, \mathrm{K}^{+}$, and $\mathrm{Mg}^{+2}$ found confirm the values reported in the literature for areas with pastures in Typic Hapludults (BERNARDI et al., 2014; LIMA et al., 2014; BARBIERI et al., 2017) and show a trend of variation of these chemical attributes in pastures, which can be due to the soil fertilization used.

The values of $\mathrm{P}$ were very heterogeneous regarding spatial distribution, which can be attributed the low mobility of $\mathrm{P}$ in the soil, its low availability in acidic soils, and its high variation in short distances because of its rapid complexation when phosphate fertilizers are applied in these soils. The soils of the study region are very weathered, with high oxide contents, especially iron oxide; usually, in high soil acidity conditions, the surface of these oxides are charged positively, attracting anions such as phosphate, forming inner sphere complexes with the iron oxides, decreasing its availability to plants (FERNANDES; SOUZA; SANTOS, 2018).

The whole study area had uniform applications of fertilizer and lime, but presented spots with different grass yield potentials; thus, the demand for chemical attributes was also different, as showed by the heterogeneity of $\mathrm{P}$ contents in the soil. Contrasting results were found for $\mathrm{pH}$, which presented low variability in the study area. Similar results were found by Pias et al. (2015) while studying the variability of dry matter yield of Tifton 85 and its correlations with chemical attributes in different soil layers of an area used for growing grasses for 13 years.

The results of the geostatistical analysis are shown in Table 2, which presents the semivariogram models, the range obtained, and the spatial dependence level between the samples of the study area.

Table 2. Semivariance components and spatial dependence level (SDL) of chemical attributes in two layers of a Typic Hapludult.

\begin{tabular}{|c|c|c|c|c|c|c|c|c|c|}
\hline Variable & Model $^{(1)}$ & & Semivarianc & & $\mathrm{R}^{(5)}$ & $\mathrm{SDL}^{(6)}$ & Class $^{(7)}$ & $\mathrm{R}^{2} \mathrm{CV}^{(8)}$ & $\operatorname{RSS}^{(9)}$ \\
\hline & & $\mathrm{C}^{(2)}$ & $\mathrm{C} 1^{(3)}$ & $\mathrm{C} 0+\mathrm{Cl}^{(4)}$ & $(\mathrm{m})$ & & & $(\%)$ & \\
\hline & \multicolumn{9}{|c|}{$0-0.20 \mathrm{~m}$ soil layer } \\
\hline $\mathrm{P}$ & - & $\mathrm{PNE}^{(10)}$ & - & - & - & - & - & - & - \\
\hline $\mathrm{K}$ & - & PNE & - & - & - & - & - & - & - \\
\hline $\mathrm{Ca}$ & - & PNE & - & - & - & - & - & - & - \\
\hline $\mathrm{Mg}$ & Exp & 0.0001 & 0.1471 & 0.1472 & 98.1 & 0.1 & $\mathrm{~S}$ & 95.9 & $<0.01^{(11)}$ \\
\hline $\mathrm{Al}$ & - & PNE & - & - & - & - & - & - & - \\
\hline $\mathrm{Na}$ & Exp & 0.0000 & 0.0001 & 0.0001 & 34.8 & 0.0 & S & 61.6 & $<0.01$ \\
\hline $\mathrm{H}+\mathrm{Al}$ & - & PNE & - & - & - & - & - & - & - \\
\hline $\mathrm{pH}$ & - & PNE & - & - & - & - & - & - & - \\
\hline \multirow[t]{2}{*}{ TOC } & Exp & 1.9059 & 13.2342 & 16.7342 & 80.1 & 19.1 & $\mathrm{~S}$ & 95.6 & $<0.01$ \\
\hline & \multicolumn{9}{|c|}{$0.20-0.40 \mathrm{~m}$ soil layer } \\
\hline $\mathrm{P}$ & - & PNE & - & - & - & - & - & - & - \\
\hline K & - & PNE & - & - & - & - & - & - & - \\
\hline $\mathrm{Ca}$ & - & PNE & - & - & - & - & - & - & - \\
\hline $\mathrm{Mg}$ & - & PNE & - & - & - & - & - & - & - \\
\hline $\mathrm{Al}$ & Gau & 0.259 & 0.308 & 0.566 & 80.9 & 45.67 & $\mathrm{M}$ & 92.4 & $<0.01$ \\
\hline $\mathrm{Na}$ & Exp & 0.000 & 0.000 & 0.000 & 43.8 & 19.25 & $\mathrm{~S}$ & 95.7 & $<0.01$ \\
\hline $\mathrm{H}+\mathrm{Al}$ & $\mathrm{Sph}$ & 0.010 & 6.906 & 6.916 & 31.6 & 0.15 & $\mathrm{~S}$ & 59.5 & 6.96 \\
\hline $\mathrm{pH}$ & Exp & 0.003 & 0.033 & 0.036 & 53.1 & 9.44 & S & 97.5 & $<0.01$ \\
\hline TOC & $\mathrm{Sph}$ & 0.010 & 26.650 & 26.660 & 27.1 & 0.04 & $\mathrm{~S}$ & 72.8 & 15.7 \\
\hline \multicolumn{10}{|c|}{ Grass yield of Tifton $85\left(\mathrm{~kg} \mathrm{ha}^{-1}\right)$} \\
\hline DMY & Sph & 16000 & 1254000 & 1270000 & 32.5 & 1.26 & $\mathrm{~S}$ & 72.3 & $7.09 .10^{9}$ \\
\hline
\end{tabular}

${ }^{1}$ Model $=\mathrm{Sph}-$ Spherical, Exp $=$ Exponential, $\mathrm{Gau}=$ Gaussian; ${ }^{2} \mathrm{C} 0=$ nugget effect; ${ }^{3} \mathrm{C} 1=\mathrm{Contribution} ;{ }^{4} \mathrm{C} 0+\mathrm{C} 1=\mathrm{Sill} ;$ ${ }^{5} \mathrm{R}=$ range; ${ }^{6} \mathrm{SDL}=$ spatial dependence level $(\mathrm{C} 0 /(\mathrm{C} 0+\mathrm{C} 1)) * 100 ;{ }^{7} \mathrm{Class}=\mathrm{S}-$ Strong, $\mathrm{M}-\mathrm{Moderate} ;{ }^{8} \mathrm{R}{ }^{2} \mathrm{CV}=\mathrm{coefficient}$ of determination of the cross validation; ${ }^{9} \mathrm{RSS}=$ residual sum of squares; ${ }^{10} \mathrm{PNE}=$ pure nugget effect; ${ }^{11}<0.01=$ values lower than 0.01 . 
The results of the geostatistical analysis showed that the following attributes presented no structure of spatial dependence in the sampling scale used: $\mathrm{P}, \mathrm{K}^{+}$, and $\mathrm{Ca}^{+2}$ in both evaluated layers; $\mathrm{Al}^{+3}, \mathrm{H}+\mathrm{Al}$, and $\mathrm{pH}$ in the $0-0.20 \mathrm{~m}$ layer; and $\mathrm{Mg}^{+2}$ in the $0.20-0.40 \mathrm{~m}$ layer. These attributes presented pure nugget effect (PNE), i.e., absence of spatial dependence, indicating random spatial distribution and, in these cases, the classical statistics is the method to be used (YAMAMOTO; LANDIM, 2013). This denotes that the number of samples used for the study of these parameters was not sufficient to detect spatial dependence and, in these cases, a higher density of samples could be considered for a revaluation of their spatial dependence.

Similar results for phosphorus were found by Bernardi et al. (2014) and Lima et al. (2014), who found higher spatial variability and absence of spatial dependence for a Typic Hapludult.

The analyses (Table 2) showed that, in the 0-0.20 $\mathrm{m}$ soil layer, the chemical attributes $\mathrm{Mg}^{+2}$, $\mathrm{Na}^{+}$, and TOC fitted to the exponential semivariogram model; and in the $0.20-0.40 \mathrm{~m}$ layer, the attributes $\mathrm{Na}^{+}$and $\mathrm{pH}$ fitted to the exponential model, while $\mathrm{H}+\mathrm{Al}$ and $\mathrm{TOC}$ fitted to the spherical model, and $\mathrm{Al}^{+3}$ to the gaussian model. The dry matter yield (DMY) of Tifton 85 fitted to the spherical model.

These results are in accordance with those found in several studies, showing that spherical and exponential models occur more frequently than other models (ARTUR et al., 2014; LEITE et al., 2015; BARBIERI et al., 2017) and are commonly attributed to soil and plant dynamics (CAMBARDELLA et al., 1994).

The coefficient of determination of the cross validation $\left(\mathrm{R}^{2} \mathrm{CV}\right)$ showed good fit, with values above 0.70 for most attributes, indicating that at least $70 \%$ of the existing variability in the values of semivariance are explained by the models.

The spatial dependence level (SDL), evaluated according to Cambardella et al. (1994), showed a strong spatial dependence for DMY, as well as all parameters that fitted to semivariogram models in the $0-0.20 \mathrm{~m}$ layer $\left(\mathrm{Mg}^{+2}, \mathrm{Na}^{+}\right.$, and TOC), indicating a high correlation between the samples. In the layer of $0.20-0.40 \mathrm{~m}$, all chemical attributes that fitted to semivariogram models presented strong spatial dependence $\left(\mathrm{Na}^{+}, \mathrm{H}+\mathrm{Al}, \mathrm{pH}\right.$, and TOC), except $\mathrm{Al}^{+3}$, which presented moderate spatial dependence, indicating a possibility of estimating the pattern of this attribute with the samples used. According to Cambardella et al. (1994), strong spatial dependence of soil chemical attributes is due to intrinsic factors, such as origin material, mineralogy, and texture; and the moderate and weak spatial dependences are due to extrinsic factors, such as soil management.

The range, which is the distance up to the sample points are correlated (VIEIRA et al., 1983), presented different results (Table 2). In the 0-0.20 m layer, the lowest range was found for $\mathrm{Na}^{+}(34.8 \mathrm{~m})$, while the highest ranges were found for TOC $(80.1 \mathrm{~m})$ and $\mathrm{Mg}^{+2}(98.1 \mathrm{~m})$. In the $0.20-0.40 \mathrm{~m}$ layer, the lowest ranges were found for TOC $(27.1 \mathrm{~m})$ and $\mathrm{H}+\mathrm{Al}(31.6 \mathrm{~m})$, and the highest ones for $\mathrm{pH}(53.1 \mathrm{~m})$ and $\mathrm{Al}^{+3}(80.9 \mathrm{~m})$.

The evaluation of DMY showed range of $32.5 \mathrm{~m}$, i.e., the points located in an area whose radius is the range are more similar to each other than those in longer distances, and can be used to estimate values for any point between them, which is important for the determination of the limit for spatial dependence (ARTUR et al., 2014).

Maps were developed for the different variables estimated by ordinary kriging (Figure 2), with the values grouped in classes of colors in increasing order.

Pearson's linear correlation was used (Figure 3 ), simultaneously to the development of the spatial variability maps, to improve the discussion about the correlations between soil chemical attributes and their effects in the grass yield of Tifton 85 .

The DMY map (Figure 2I) showed the different grass yield of Tifton 85 in relation to the general mean. The mean grass yield found in the area was $2.248 \mathrm{~kg} \mathrm{ha}^{-1}$. The spatial variability map of grass yield showed that the south and southwest regions of the area presented higher grass yields (within the very high class), with little spots of this class distributed over the study area.

The grass yields of the north, northeast, and east regions of the study area were classified as high. The lowest grass yield was found in the west region, which presented low and very low grass yield classes; these grass yield classes were also found, in smaller to a lesser extent, in the east and northeast of the area. 


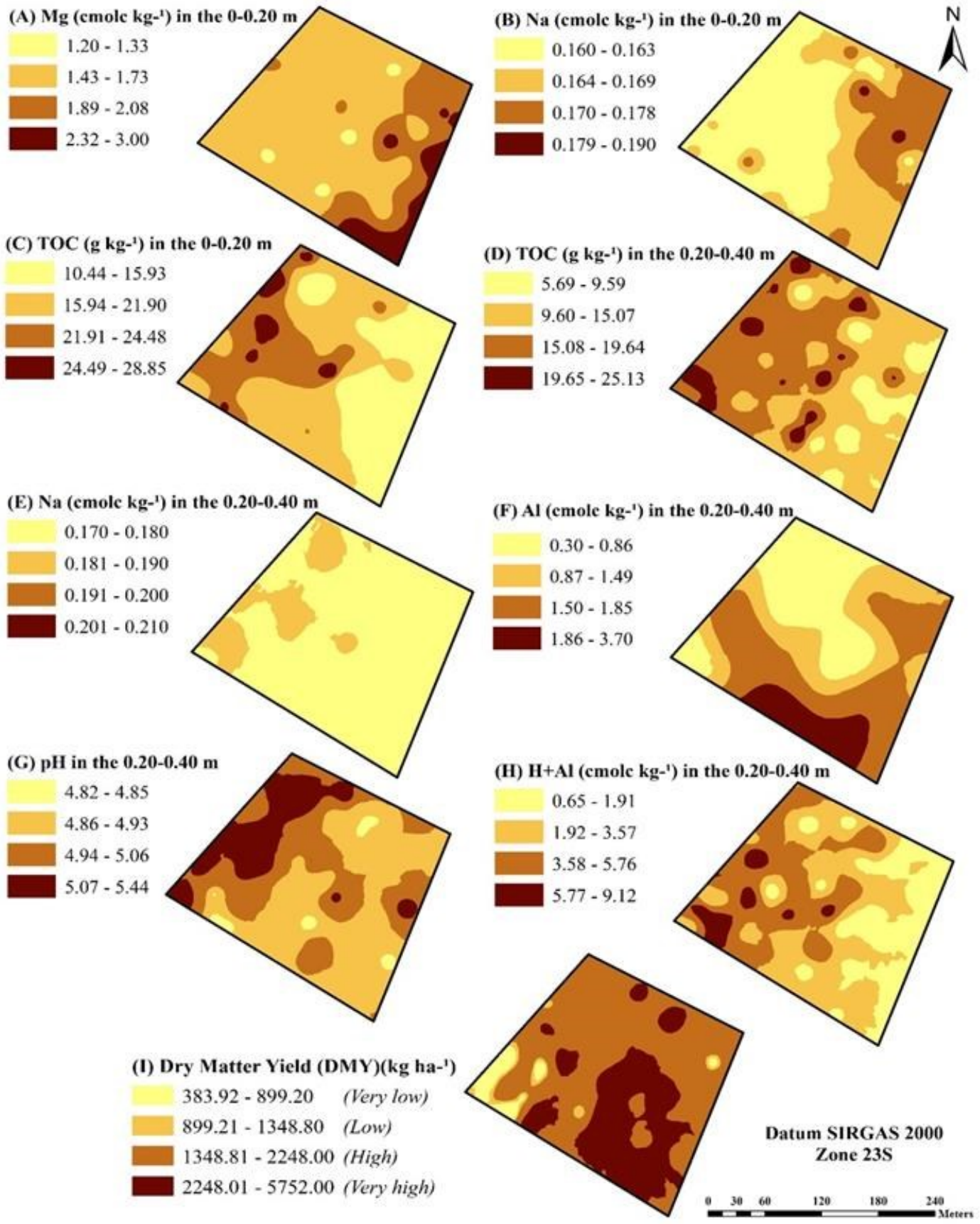

Figure 2. Spatial variability for $\mathrm{Mg}^{+2}\left(\mathrm{cmol}_{\mathrm{c}} \mathrm{kg}^{-1}\right), \mathrm{Na}^{+}\left(\mathrm{cmol}_{\mathrm{c}} \mathrm{kg}^{-1}\right)$, and total organic carbon (TOC) $\left(\mathrm{g} \mathrm{kg}^{-1}\right)$ in the $0-0.20 \mathrm{~m}$ soil layer (Figures A, B, C); for TOC $\left(\mathrm{g} \mathrm{kg}^{-1}\right), \mathrm{Na}^{+}\left(\mathrm{cmol}_{\mathrm{c}} \mathrm{kg}^{-1}\right), \mathrm{Al}^{+3}\left(\mathrm{cmol}_{\mathrm{c}} \mathrm{kg}^{-1}\right), \mathrm{pH}$, and $\mathrm{H}+\mathrm{A}\left(\mathrm{cmol}_{\mathrm{c}} \mathrm{kg}^{-1}\right)$ in the 0.20 $0.40 \mathrm{~m}$ soil layer (Figures D, E, F , G, H); and for dry matter yield (DMY) $\left(\mathrm{kg} \mathrm{ha}^{-1}\right)$ (Figure I).

Floodable areas were observed in the west region of the area after occurrence of higher rainfall depths. This can be related to soil physical factors, such as soil water infiltration and storage capacities and soil compaction. The growth of plants decreases significantly due to chemical (acidity, and toxicity by $\mathrm{Al}^{+3}$ ) and physical-hydrological (flood) problems and presence of compacted soil layers (FERNANDES; SOUZA; SANTOS, 2018), which are factors that may be affecting negatively the grass yield in this region.
According to the criteria of classification of Freire et al. (2013), $\mathrm{K}$ contents were low $(\mathrm{K}<$ $\left.0.115 \mathrm{cmol}_{\mathrm{c}} \mathrm{dm}^{-3}\right)$ and medium $(0.115<\mathrm{K}>$ $0.23 \mathrm{cmol}_{\mathrm{c}} \mathrm{dm}^{-3}$ ) in the $0-0.20 \mathrm{~m}$ layer, and low in the in 0.20-0.40 m layer. Coutinho et al. (2014) reported that the Tifton 85 grass has a high nutritional demand, especially for $\mathrm{K}$. Thus, the $\mathrm{K}^{+}$results found denote that this nutrient contents in the study area could be limiting the development of these plants.

According to Rezende et al. (2015), K can be a limiting factor for the growth of grass species due to its low available contents in tropical soils and the 
A) Pearson's linear correlation

for the $0-0.20 \mathrm{~m}$ soil layer
B) Pearson's linear correlation

for the $0.20-0.40 \mathrm{~m}$ soil layer
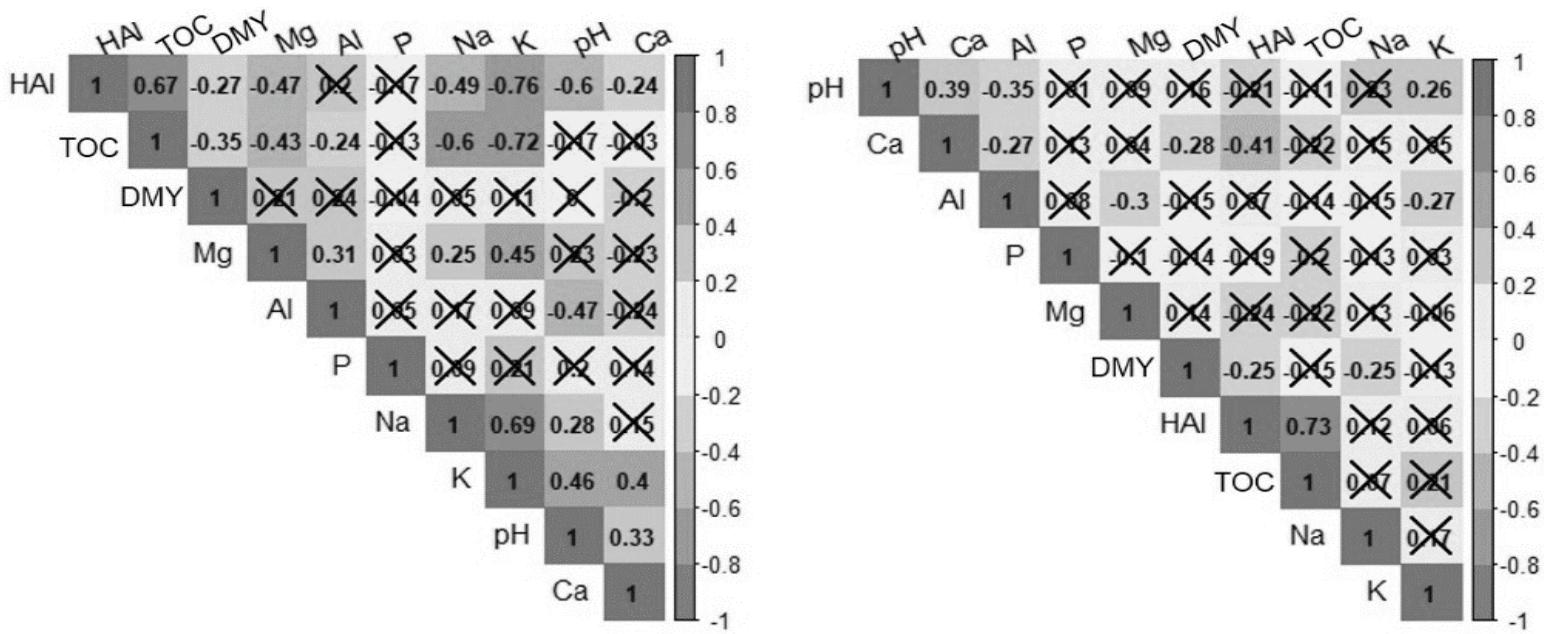

Figure 3. Pearson's linear correlation for chemical attributes and grass yield (DMY) of the $0-0.20 \mathrm{~m}$ (A) and $0.20-0.40 \mathrm{~m}$ (B) soil layers, at 10\% significance, generated in the corrplot bibliotheca of the R program. Values crossed with $\mathrm{X}$ were not significant, i.e., presented no significant correlation at $10 \%$ significance.

physiological functions of this nutrient in the plant; and, when underestimated, it can affect the response of forage species to fertilizations with other nutrients. The $\mathrm{Ca}^{+2}$ and $\mathrm{Mg}^{+2}$ contents (Figure 2A) in most points sampled in the $0-0.20 \mathrm{~m}$ layer were above the demand of the plants $\left(\mathrm{Ca}+\mathrm{Mg}>2.8 \mathrm{cmol}_{\mathrm{c}}\right.$ $\mathrm{dm}^{-3}$ ), while in the $0.20-0.40 \mathrm{~m}$ layer they were below this value. The regions with higher grass yield, in the south of the DMY map, were the ones that presented higher $\mathrm{K}^{+}, \mathrm{Mg}^{+2}$, and $\mathrm{pH}$ values in the $0-0.20 \mathrm{~m}$ layer, which is the layer with higher concentration of Tifton 85 roots.

$\mathrm{Ca}^{+2}$ and $\mathrm{Na}^{+}$contents (Figure 2E) in the 0.20-0.40 $\mathrm{m}$ presented significant negative correlation with DMY (Figure 3B); they limited the development of the plants because of their low availability in this soil layer.

$\mathrm{Al}^{+3}$ contents were high in the whole area $\left(\mathrm{Al}>0.3 \mathrm{cmol}_{\mathrm{c}} \mathrm{dm}^{-3}\right.$ ) (Figure $2 \mathrm{~F}$ ), requiring a more refined approach to recommend liming rates to correct the soil acidity in the area. Results of efficacy of liming in soils with pastures, including Tifton 85, are reported in the literature, confirmed by increases in $\mathrm{pH}, \mathrm{Ca}^{+2}$ and $\mathrm{Mg}^{+2}$ contents, and base saturation of the soil (COUTINHO et al., 2014). Moreover, high $\mathrm{Al}^{+3}$ contents affect the root system of plants, changing their morphology and root growth, generating an unfavorable plant growth and development (FERNANDES; SOUZA; SANTOS, 2018).

The soil acidity was high for the plants, with mean $\mathrm{pH}$ of approximately 5.0 for both soils layers (Figure 2G); pH above 5.5 are recommended for production of tropical forages. Moreover, $\mathrm{pH}$ is the main factor that controls $\mathrm{Al}$ concentration in the soil solution. The solubility of Al is very low or null at $\mathrm{pH}$ above 5.5, and its toxicity is particularly strong at $\mathrm{pH}$ below 5 (FERNANDES; SOUZA; SANTOS, 2018). The correlation between these variables was found in the study area and confirmed by the significant correlation between $\mathrm{Al}$ and $\mathrm{pH}$ (Figures $3 \mathrm{~A}$ and $3 \mathrm{~B}$ ).

The TOC contents in both layers were classified as medium (11-20 $\left.\mathrm{g} \mathrm{kg}^{-1}\right)$ and high $\left(>20 \mathrm{~g} \mathrm{~kg}^{-1}\right)$. The highest TOC contents were found in the 0-0.20 m layer (Figure 2C) (Figure 2D). This result is due to the preferential accumulation of organic carbon in the soil surface layers because of the deposition and decomposition of the plant residues on the soil surface.

Moreover, the roots of Tifton 85 plants are very dense and concentrated in the $0-0.10 \mathrm{~m}$ layer, acting directly as a source of organic carbon, since they temporarily immobilize the carbon in their root biomass, releasing it to the soil after their senescence; thus, they can also affect the TOC contents

TOC and DMY (Figure 3A) presented significant Pearson's linear correlation at $10 \%$ significance, indicating a correlation between soil carbon contents and grass yield. The carbon in the soil can be absorbed and used by plants for biomass production, increasing their DMY. The west region of the variability maps for TOC and DMY (Figures 2C, 2D and 2I) presented significantly higher TOC contents and lower DMY than the other regions of the map.

Considering these results and that TOC contents depends on the amount of organic matter and its decomposition/mineralization process in the 
soil, it is important to further the discussion about the soil organic matter compartments and labile and stable fractions that can also influence and increase or decrease grass yield of Tifton 85 .

Considering that the soil used was a Typic Hapludult, the soil base saturation is naturally lower than $50 \%$, thus, the soil of the area presents low natural fertility. This characteristic combined with the low $\mathrm{pH}$ found resulted in a high potential acidity $(\mathrm{H}+\mathrm{Al})$, especially in the east, northwest, and central regions of the $\mathrm{H}+\mathrm{Al}$ map (Figure $2 \mathrm{H}$ ). This is confirmed by the Pearson's linear correlation at $10 \%$ significance for $\mathrm{DMY}$ and $\mathrm{H}+\mathrm{Al}$, showing the negative effect on grass yield due to the higher $\mathrm{H}+\mathrm{Al}$ concentration in both evaluated layers (Figures 3A and $3 \mathrm{~B}$ ).

Considering the results found, the development of maps over the cycle of Tifton 85 plants is important for the comprehension of the variability in DMY; the identification of these differences can be used as guidelines in the search for adequate managements for these pasture areas, such as localized soil fertilization and liming, and in the development of maps for recommendation of localized application of inputs.

Therefore, the investigation of areas with different productive potentials should be followed by maps of soil chemical attributes to correlate and understand the ratios that can be involved with the variations, mainly in areas that present low grass yields.

\section{CONCLUSIONS}

The parameters $\mathrm{Mg}^{+2}, \mathrm{Na}^{+}$, and total organic carbon (TOC) contents in the $0-0.20 \mathrm{~m}$ soil layer, and $\mathrm{Na}^{+}$and $\mathrm{pH}$ in the $0.20-0.40 \mathrm{~m}$ soil layer fitted to the exponential model; $\mathrm{H}+\mathrm{Al}$ and TOC in the 0.20 $0.40 \mathrm{~m}$ soil layer and dry matter yield (DMY) fitted to the spherical model; and $\mathrm{Al}^{+3}$ in the $0.20-0.40 \mathrm{~m}$ soil layer fitted to the gaussian model.

The spatial dependence of all chemical attributes that presented fit to the semivariogram was classified as strong or moderate.

The soil chemical parameters $\mathrm{Na}^{+}, \mathrm{Ca}^{+2}$, TOC, and $\mathrm{H}+\mathrm{Al}$ presented significant correlation with DMY, confirming their importance and interference in the grass yield of Tifton 85 .

The west region of the experimental area presented high potential acidity $(\mathrm{H}+\mathrm{Al})$ and floodable areas in rainfall periods, affecting negatively the DMY.

The georeferenced soil sampling method and the development of maps allowed the visualization of the spatial variability of the soil chemical attributes and DMY of Tifton 85, showing the need for localized soil fertilization and liming in the area.

\section{REFERENCES}

ALMEIDA, J. C. C. et al. Nutritive value of Tifton 85 hay ammoniated with urea. Acta Scientiarum. Animal Sciences, 41: e42473, 2019.

AQUINO, R. E. et al. Geoestatística na avaliação dos atributos físicos em Latossolo sob floresta nativa e pastagem na Região de Manicoré, Amazonas. Revista Brasileira de Ciência do Solo, 38: 397 406, 2014.

ARTUR, A. G. et al. Variabilidade espacial dos atributos químicos do solo, associada ao microrrelevo. Revista Brasileira de Engenharia Agrícola e Ambiental, 18: 141-149, 2014.

BARBIERI, R. S. et al. Variabilidade de atributos físicos e químicos para recuperação de um Argissolo Vermelho sob pastagem degradada no Cerrado. Revista Espacios, 38: 1-18, 2017.

BERNARDI, A. C. C. et al. Variabilidade espacial de parâmetros físico-químicas do solo e biofísicos de superfície em cultivo do sorgo. Revista Brasileira de Engenharia Agrícola e Ambiental, 18: 623-630, 2014

CAMBARDELLA, C. A. et al. Field-scale variability of soil properties in central Iowa soils. Soil Science Society of AmericaJournal, 58: 15011511, 1994.

CARVALHO, J. R. P.; SILVEIRA, P. M.; VIEIRA, S. R. Geoestatística na determinação da variabilidade espacial de características químicas do solo sob diferentes preparos. Pesquisa Agropecuária Brasileira, 37: 1151-1159, 2002.

COLUSSI, G; SILVA, L. S.; MINATO, E. A. Escarificação e adubação orgânica: efeito na recuperação estrutural de solo produzindo Tifton 85 . Ciência Rural, 44: 1956-1961, 2014.

COUTINHO, E. L. et al. Calagem e adubação potássica para o capim-Tifton 85. Bioscience Journal, 30: 101-111, 2014

DELGADO, F. M. AgricolaeR: a package for estatistical analysis. Departamento de Estatística e Informática, Universidade Nacional Agrária La Molina, Peru, 2018.

ENVIRONMENTAL SYSTEMS RESEARCH INSTITUTE - ESRI. ArcGIS ${ }^{\circledR}$ 10.5.2: New Release Transforms Enterprise GIS. Redlands, 2016.

FERNANDES, M. S.; SOUZA, S. R.; SANTOS, L. A. Nutrição Mineral de Plantas. 2. ed. Viçosa, MG: SBCS, 2018. 670 p. 
FREIRE, L. R et al. Manual de calagem e adubação do Estado do Rio de Janeiro. 1. ed. Brasília, DF: Embrapa; Seropédica, RJ: Editora Universidade Rural, 2013. 430 p.

GIOSTRI, A. F. et al. Resíduo de indústria de enzimas no crescimento da pastagem e propriedades químicas do solo. Acta Scientiarum. Agronomy, 36: 247-257, 2014.

GOMES, E. P. et al. Produtividade de pastagem de capim Tifton 85 irrigado e sobressemeada com forrageiras de inverno. Acta Scientiarum. Animal Sciences, 37: 123-128, 2015.

ISAAKS, E. H.; SRIVASTAVA, R. M. An introduction to applied geostatistics. 1. ed. New York: Oxford University, 1989. 561 p.

LEITE, L. F. C. et al. Variabilidade espacial das frações da matéria orgânica do solo em área degradada sob recuperação. Revista Brasileira de Engenharia Agrícola e Ambiental, 19: 394-401, 2015.

LIMA, G. C. et al. Variabilidade de atributos do solo sob pastagens e mata atlântica na escala de microbacia hidrográfica. Revista Brasileira de Engenharia Agrícola e Ambiental, 18: 517-526, 2014.

PIAS, O. H. C. et al. Mapeamento da produção de massa seca do Tifton 85 e sua correlação com os atributos químicos do solo. Semina: Ciências Agrárias. 36: 2093-2104, 2015.

PIMENTEL-GOMES, F.; GARCIA, C. H. Estatística aplicada a experimentos agronômicos e florestais. 1. ed. Piracicaba, SP: FEALQ, 2002. $309 \mathrm{p}$.

POCZYNEC, M. et al. Capacidade produtiva e qualidade nutricional de gramíneas perenes submetidas a sistema contínuo de cortes. Arquivo Brasileiro de Medicina Veterinária e Zootecnia, 68: 785-794, 2016.

RAMOS, D. P.; CASTRO, A. F.; CAMARGO, M. N. Levantamento detalhado de solos da área da Universidade Federal Rural do Rio de Janeiro. Pesquisa Agropecuária Brasileira, 8: 1-27, 1973.

REZENDE, A. V. et al. Características estruturais, produtivas e bromatológicas dos capins Tifton 85 e Jiggs fertilizados com alguns macronutrientes. Semina: Ciências Agrárias, 36: 1507-1518, 2015.
RIBEIRO JUNIOR, P. J.; DIGGLE, P. J. GeoR: a packagef or geostatistical analysis. R-News, 1: 14$18,2001$.

SIMÕES, C. R. et al. Imagens multiespectrais para avaliação de índice de área foliar e massa seca do capim 'Tifton 85', sob adubação nitrogenada. Ciência Rural, 45: 697-703, 2015.

SOARES, M. D. R. et al. Variabilidade espacial dos atributos do solo sob agroflorestal na região de Humaitá, AM. Gaia Scientia, 12: 33-41, 2018.

TEIXEIRA, P. C. et al. Manual de métodos de análise de solo. 3. ed. rev. e ampl. Brasília, DF: Embrapa, 2017. 573 p.

VIEIRA, S. R. et al. Geoestatistical theory and application to variability of some agronomical properties. Hilgardia, 51: 1-75, 1983.

YAMAMOTO, J. K.; LANDIM, P. M. B. Geoestatística: conceitos e aplicações. 1. ed. São Paulo, SP: Oficina de Textos, 2013. 215 p.

YEOMANS, J. C.; BREMNER, J. M. A rapid and precise method for routine determination of organic carbon in soil. Communications in Soil Science and Plant Analysis, 19: 1467-1476, 1988. 